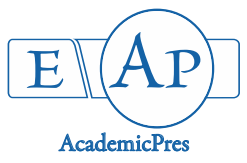

Bamigboye $\mathrm{MO}$ and Ajiboye AE (2020)

Notulae Scientia Biologicae 12(3):619-627

DOI: $10.15835 / \mathrm{nsb} 12310780$

Research Article



\title{
Synthesis and antimicrobial activities of a metallic oxide nanoparticle complex of Moringa oleifera leaves extracts against selected microorganisms
}

\author{
Mercy O. BAMIGBOYE ${ }^{1 *}$, Adeyinka E. AJIBOYE ${ }^{2}$ \\ ${ }^{1}$ University of Ilorin, Faculty of Physical Sciences, Department of Industrial Chemistry, Ilorin, \\ Nigeria; obaleye.mo@unilorin.edu.ng ("corresponding author) \\ ${ }^{2}$ Kwara State University, Faculty of Pure and Applied Sciences, Department of Biosciences and Biotechnology, Microbiology Unit, \\ Malete, Kwara State, Nigeria; adeyinka.ajiboye@kwasu.edu.ng
}

\begin{abstract}
This research work aimed at synthesizing and investigating the antimicrobial activities of a metallic oxide nanoparticle complex of Moringa oleifera leaves extracts against some microorganisms. Moringa oleifera leaves were washed, dried and blended. They were extracted with distilled water and ethanol using standard methods. The nanoparticle was synthesized by coordinating with manganese oxide. The physicochemical properties were determined following standard procedures. The phytochemical screening was carried out by standard methods. The antibacterial activities were done using agar well diffusion method. Antifungal activity was carried out following the plate technique. The leaves extract had a $75 \%$ yield and melting point of $116^{\circ} \mathrm{C}$ while the nanoparticle had a yield of $60 \%$ and melted at $78^{\circ} \mathrm{C}$ with $\mathrm{pH}$ of 3.46 . The molar conductance of the nanoparticle revealed at $10.6 \Omega^{-1} \mathrm{~cm}^{2} \mathrm{~mol}^{-1}$. The ethanolic extract of the leaves showed the presence of alkaloids, tannin, steroids and saponins. The ethanolic extract of $M$. oleifera exhibited the highest antibacterial activity of $33.05 \pm 0.10 \mathrm{~mm}$ against Bacillus subtilis while its antifungal activity revealed the highest inhibition of $48.40 \pm 0.53 \mathrm{~mm}$ at $30 \mathrm{mg} / \mathrm{mL}$ against Aspergillus niger. Staphylococcus aureus had a zone of inhibition of $19.00 \pm 0.16^{a}$ using the aqueous extract. The ethanolic extract of $M$. oleifera nanoparticles showed antibacterial and antifungal activity against $B$. megaterium and $A$. niger with a zone of inhibition of $49.21 \pm 0.32 \mathrm{~mm}$ and $50.35 \pm 0.29 \mathrm{~mm}$ respectively while the aqueous extract showed antibacterial activity against $S$. aureus with a zone of $26.00 \pm 0.38 \mathrm{~mm}$. As it was concluded ethanolic extract in both leaves extract and its nanoparticle, possessed higher antibacterial and antifungal activities than the aqueous extract.
\end{abstract}

Keywords: aqueous; ethanolic; extract; manganese oxide; Moringa oleifera; nanoparticle

\section{Introduction}

Nano-techonology has enhanced our daily lives quietly and significantly with the help of researchers globally (Wong et al., 2001). Different nanoparticles have been studied due to nano-dimension, nanostructured materials which are analysed by irregular electronics and mechanical properties. Coordination and characterization of some nanoscale materials are important to scientific studies which grow rapidly as a 
result of their usefulness for producing new products for virtually all areas of human activity including medicine and communication. Nanotechnology has great a concern in enhancing the treatment of different disorders and diagnostics. (Cagin et al., 1999). The metallic nanoparticles have been produced through the borohydride reduction method at a determined temperature (Jana and Gearheart, 2001). From previous research, studies on nanoscale material based on some selected metals such as copper, cobalt, nickel and iron have been done due to their physicochemical properties and potential use of technology for keeping information.

Moringa oleifera leaves are used as a local source for a target in the development of biomaterials, bionanotechnology and engineering. Importantly, Moringa oleifera leaves powder constitute high concentration of some organic materials MaryKensa and Neelamegam (2014). Moringa is a local plant in Africa and Asia which are mostly grown in North Western India. It is the sole genus in the family of Moringaceae. It has about thirteen species from tropical and subtropical climates within the range of tiny herbs to massive trees (Azwanida, 2015).

Several works have been performed on the beneficial effects in humans. It is well known as having a large number of bioactive compounds. The part used most is the leaves which are very rich in vitamins, polyphenols, flavonoids, alkaloids, glucosinolates, tannins, saponins e.t.c. The number of bioactive compounds helps to describe the pharmacological properties of Moringa oleifera leaves. Researchers have proven the pharmacological properties of the plant. Few years back, synthesis of different forms of active antimalarial substances from the leaves have been on the increase (Yakubu et al., 2006).

$M$. oleifera plant has recently generated great attention as potential therapeutic agents against different diseases like those involving radical damage. These polyphenolic compounds, ubiquitous in higher plants, are commonly major dietary constituents. The biological and medicinal properties of flavonoids have been reviewed extensively, with wealth of data on their activity as reducing agents, hydrogen-donating antioxidant, and singlet oxygen quenchers (MaryKensa and Neelamegam, 2014).

M. oleifera are natural chelators and its metal complexes have been shown to possess high cytotoxic activity (Ramakrishna and Pragna (2011) which has great benefits in curing various diseases. It has also been shown that synthesis of metals with bioactive ligands can enhanced the pharmaceutical activity of the drugs and help to decrease their toxicity effects (Enemose et al., 2014). From previous work, Doddanna et al., 2013) showed the activity of some plant extracts against Candida albicans. It was observed that the results obtained revealed that the ethanolic extract of curry leaves are effective against Candida albicans with $24.05 \pm 0.07$ after 48 hours. According to Alzoreky and Nakahara (2003) and Castro et al. (2008), the antimicrobial activities of some parts of plants has been carried out. These include crude extracts of cinnamon, curry and ginger mustard, and other herbs which possessed antimicrobial properties against gram-positive and gram-negative organisms. It has also been observed that the extracts obtained from Chinese chives and cassia can actively help to reduce the rate at which Escherichia coli and other organisms develop during storage of meat, juices, and milk (Mau et al., 2001).

\section{Materials and Methods}

\section{Preparation of aqueous and ethanolic extract of Moringa oleifera leaves}

Procedure followed by Bamigboye and Ahmed (2019) was adopted for this research work. Fresh Moringa oleifera leaves were collected from the environment of University of Ilorin, Nigeria. The leaves were freed from twigs and extraneous matter. In order to remove the dirt of foreign matter, the samples were thoroughly washed with distilled water and dried. After drying, the leaves were grinded into a fine powder with the use of mortar and pestle. About $10 \mathrm{~g}$ of the powder was then weighed and soaked into a separate round bottom flask of distilled water and ethanol. Each of the contained flasks was heated for 30 minutes at $100{ }^{\circ} \mathrm{C}$ and $78^{\circ} \mathrm{C}$ respectively. They were incubated at $37^{\circ} \mathrm{C}$ and $130 \mathrm{rpm}$ in a shaking incubator (Kahlil et al., 2013). 
The extracts were separated by filtration with the use of Whatman No. 1 filter and concentrated using rotary evaporator.

\section{Synthesis of Moringa oleifera leaves-manganese oxide nanoparticles}

The procedure of Pirtarighat et al. (2019) was adopted. Briefly, an aqueous solution of manganese oxide $(\mathrm{MnO})(1 \mathrm{mM})$ was prepared and mixed in different beakers with aqueous and ethanolic extracts of $M$. oleifera leaves respectively. Each mixed solution was introduced into a shaker at a determined temperature for about 3 hours. It was decanted and dried. The product was kept in a sample bottle for further analysis.

\section{Determination of phytochemical constituents of leaves extracts of $M$. oleifera}

The phytochemical constituents of $M$. oleifera leaves extract were determined by the procedures adapted by Ahmed et al. (2013). They include steroids, alkaloids, saponins and tannins.

Test for alkaloids: In the leaves extract, about 5 percent drop of $1 \mathrm{~mL}$ of leaves extract was added to 2 $\mathrm{mL}$ of $1 \% \mathrm{HCl}$ for 20 minutes. The mixed extract was left to cool. After it was filtered, 2 drops of picric acid were introduced into it. A form of cream precipitate was obtained. This revealed the presence of an alkaloid in the leaves extract.

Test for saponins: $10 \mathrm{~mL}$ of distilled water was measured and added to the aqueous and ethanolic extracts in each test tube. Frothing was introduced to a few drops of olive oil. A form of foam showed the presence of saponin.

Test for steroids: About two drops of hydrogen tetraoxosulphate (VI) acid were added to about $1 \mathrm{~mL}$ of the leafs extracts. A form of red colour was observed revealing the presence of steroid in the leaves extract.

Test for tannins: Bromine water $(7 \mathrm{~mL})$ was introduced to the ethanolic and aqueous leaves extract. The bromine water was decolorized, revealing the presence of tannins.

\section{Collection and maintenance of test microorganisms}

The Bacterial isolates include Escherichia coli, Bacillus megaterium, Staphylococcus aureus, Pseudomonas aeruginosa and Bacillus subtilis, and fungal isolates used were Aspergillus niger, Candida albicans, and Penicillium chrysogenum. They were collected from the Department of Microbiology, Lagos State University, Lagos State, Nigeria. They were aseptically sub-cultured in appropriate agar slants and maintained in the refrigerator at temperature of $4^{\circ} \mathrm{C}$ until further use.

\section{Antimicrobial activities}

Antibacterial activity of the leaves extract and nanoparticles were done using agar well diffusion method as adopted by Daoud et al. (2015) and Bamigboye and Ahmed (2019). About $1 \mathrm{~mL}$ of bacterial culture was pipetted into the centre of the prepared sterile Petri dish. Nutrient agar was then introduced into the Petri dish which contained the inoculum. Upon solidification, holes of $5 \mathrm{~mm}$ were drilled with the use of a sterile cork borer into the agar plates. About $0.1 \mathrm{~mL}$ of ethanolic and aqueous extracts were introduced into each hole. The agar plates could stay for about 30 minutes in order to allow the extracts diffuse well into the agar. Thereafter, the plates were incubated at $37^{\circ} \mathrm{C}$ for 24 hours. Zone of inhibition were determined with use of a metre rule.

Procedure followed by Ahmed et al. (2013) was followed in carrying out the antifungal activity. Poisoned plate technique was used for the antifungal activity. Mycelial plugs from the margins of each plate was removed with the use of a cork borer. The nanoparticle was affixed at the middle of the solidified sterile potato dextrose agar plate. The agar plates were incubated at $28 \pm 2{ }^{\circ} \mathrm{C}$ for about 72 hours. The growth was determined and recorded. Both the antibacterial and antifungal activities were carried out for the leaves extracts and its nanoparticles. 


\section{Statistical analysis}

The results were statistically analysed by expressing as mean and standard deviation of triplicates readings using ANOVA of SPSS statistical package of Minitab software 2011 version. Values were considered significant at $\mathrm{p}<0.05$

\section{Results}

The physicochemical properties of Moringa oleifera leaves extract and its nanoparticle is presented in Table 1. The melting points of the leaves extract and its nanoparticle are 116 and $78{ }^{\circ} \mathrm{C}$ respectively. The phytochemical screening of the aqueous and ethanolic leaves extracts of $M$. oleifera revealed the presence of alkaloid, saponin, steroid and tannin in the ethanolic extracts while they were absent in the aqueous extract (Table 2). The antibacterial and antifungal activities of the leaves extracts indicated that the ethanolic extract exhibited a better activity than the aqueous extract as presented in Tables 3 and 4 . The ethanolic leaves extract of $M$. Oleifera exhibited highest antibacterial activity against $B$. subtilis with a zone of $33.00 \pm 0.30^{\mathrm{b}} \mathrm{mm}$ at 30 $\mathrm{mg} / \mathrm{mL}$ while the lowest zone of inhibition was observed to be $1.00 \pm 0.48^{\mathrm{a}} \mathrm{mm}$ at concentration of $10 \mathrm{mg} / \mathrm{mL}$ against Staphylococcus aureus with the aqueous extract. The ethanolic extract exhibited antifungal activity against Aspergillus niger with the highest zone of inhibition of $48.00 \pm 0.53^{\mathrm{b}} \mathrm{mm}$ at concentration of $30 \mathrm{mg} / \mathrm{mL}$ while the lowest zone of $2.00 \pm 0.47^{\mathrm{b}} \mathrm{mm}$ was observed against Penicillium chrysogenum at concentration of 10 $\mathrm{mg} / \mathrm{mL}$ with the aqueous extract. The antibacterial and antifungal activities of the leaves extract nanoparticles are presented in Tables 5 and 6 . According to the data obtained, the ethanolic leaves extract of $M$. oleifera nanoparticles exhibited highest antibacterial activity against $B$. megaterium with a zone of $49.00 \pm 0.32 \mathrm{~mm}$ at $30 \mathrm{mg} / \mathrm{mL}$ (Table 5). The highest antifungal activity of the ethanolic leaves extract was shown against Aspergillus niger with a zone of inhibition of $50.00 \pm 0.29 \mathrm{~mm}$ while the highest activity for the aqueous leaves nanoparticles was found to be $29.00 \pm 0.39^{\mathrm{b}} \mathrm{mm}$ against Penicillium chrysogenum as presented in Table 6 .

Table 1. The physicochemical properties of leaves extract of Moringa oleifera and its nanoparticle

\begin{tabular}{|c|c|c|c|c|}
\hline $\begin{array}{c}\text { Compounds } \\
\text { (Aqueous/Ethanol) }\end{array}$ & Yield (\%) & $\begin{array}{c}\text { Melting } \\
\text { point }\left({ }^{\circ} \mathrm{C}\right)\end{array}$ & $\mathrm{pH}$ & $\begin{array}{c}\text { Conductivity } \\
\left(\Omega^{-1} \mathrm{~cm}^{2} \mathrm{~mol}^{-1}\right)\end{array}$ \\
\hline Leaf extract & $75 / 50$ & $116 / 132$ & $3.12 / 3.33$ & - \\
\hline Nanoparticles & $60 / 44$ & $78 / 91$ & $3.46 / 3.05$ & $10.8 / 7.35$ \\
\hline
\end{tabular}

Table 2. Phytochemical screening of leaves extracts of Moringa oleifera

\begin{tabular}{|c|c|c|}
\hline Phytochemicals & aqueous extracts & Ethanol \\
\hline Alkaloid & + & ++ \\
\hline Saponin & + & ++ \\
\hline Steroid & + & ++ \\
\hline Tannin & + & ++ \\
\hline
\end{tabular}

Key: +: Slightly Present ++ : Strongly present 
Table 3. Antibacterial activity of leaves extracts of Moringa oleifera against selected bacteria

\begin{tabular}{|c|c|c|c|c|c|c|}
\hline \multirow{2}{*}{ Bacterial Isolates } & \multicolumn{3}{|c|}{$\begin{array}{c}\text { Extracts/Zones of Inhibition }(\mathrm{mm}) \\
\text { ethanolic extract }(\mathrm{mg} / \mathrm{mL})\end{array}$} & \multicolumn{3}{c|}{$\begin{array}{c}\text { Aqueous extract } \\
(\mathrm{mg} / \mathrm{mL})\end{array}$} \\
\cline { 2 - 7 } & 10 & 20 & 30 & 10 & 20 & 30 \\
\hline Escherichia coli & $15.32 \pm 0.29^{\mathrm{a}}$ & $23.65 \pm 0.47^{\mathrm{a}}$ & $28.94 \pm 0.71^{\mathrm{a}}$ & $4.36 \pm 0.26^{\mathrm{a}}$ & $7.28 \pm 0.15^{\mathrm{a}}$ & $14.39 \pm 0.36^{\mathrm{b}}$ \\
\hline $\begin{array}{c}\text { Bacillus } \\
\text { megaterium }\end{array}$ & $20.15 \pm 0.34^{\mathrm{b}}$ & $22.59 \pm 0.29^{\mathrm{b}}$ & $27.06 \pm 0.61^{\mathrm{a}}$ & $1.75 \pm 0.48^{\mathrm{a}}$ & $6.32 \pm 0.29^{\mathrm{b}}$ & $10.17 \pm 0.58^{\mathrm{b}}$ \\
\hline $\begin{array}{c}\text { Staphylococcus } \\
\text { aureus }\end{array}$ & $18.39 \pm 0.52^{\mathrm{b}}$ & $24.19 \pm 0.47^{\mathrm{a}}$ & $26.52 \pm 0.25^{\mathrm{b}}$ & $10.23 \pm 0.43^{\mathrm{b}}$ & $13.22 \pm 0.27^{\mathrm{a}}$ & $19.46 \pm 0.16^{\mathrm{a}}$ \\
\hline $\begin{array}{c}\text { Pseudomonas } \\
\text { aeruginosa }\end{array}$ & $22.42 \pm 0.18^{\mathrm{a}}$ & $24.71 \pm 0.20^{\mathrm{a}}$ & $28.17 \pm 0.44^{\mathrm{b}}$ & $5.30 \pm 0.16^{\mathrm{b}}$ & $16.18 \pm 0.45^{\mathrm{b}}$ & $19.42 \pm 0.28^{\mathrm{a}}$ \\
\hline Bacillus subtillis & $14.05 \pm 0.26^{\mathrm{b}}$ & $29.37 \pm 0.17^{\mathrm{b}}$ & $33.05 \pm 0.30^{\mathrm{b}}$ & $8.01 \pm 0.35^{\mathrm{a}}$ & $11.72 \pm 0.34^{\mathrm{a}}$ & $14.36 \pm 0.37^{\mathrm{b}}$ \\
\hline
\end{tabular}

Values are means \pm standard deviation of three replicates. Values in the same column with different superscript are significantly different at $P<0.05$.

Table 4. Antifungal activity of leaves extracts of Moringa oleifera against selected fungi

\begin{tabular}{|c|c|c|c|c|c|c|}
\hline \multirow{2}{*}{ Fungal isolates } & \multicolumn{3}{|c|}{$\begin{array}{c}\text { Extracts/Zones of Inhibition }(\mathrm{mm}) \\
\text { Ethanolic extract }(\mathrm{mg} / \mathrm{mL})\end{array}$} & \multicolumn{3}{c|}{$\begin{array}{c}\text { Aqueous extract } \\
(\mathrm{mg} / \mathrm{mL})\end{array}$} \\
\cline { 2 - 7 } & 10 & 20 & 30 & 10 & 20 & 30 \\
\hline $\begin{array}{c}\text { Candida } \\
\text { albicans }\end{array}$ & $16.20 \pm 0.15^{\mathrm{a}}$ & $27.32 \pm 0.42^{\mathrm{b}}$ & $33.54 \pm 0.10^{\mathrm{a}}$ & $9.11 \pm 0.28^{\mathrm{b}}$ & $15.09 \pm 0.36^{\mathrm{a}}$ & $18.57 \pm 0.30^{\mathrm{b}}$ \\
\hline $\begin{array}{c}\text { Aspergillus } \\
\text { niger }\end{array}$ & $36.16 \pm 0.37^{\mathrm{a}}$ & $39.05 \pm 0.15^{\mathrm{a}}$ & $48.40 \pm 0.53^{\mathrm{b}}$ & $3.35 \pm 0.16^{\mathrm{a}}$ & $7.16 \pm 0.64^{\mathrm{b}}$ & $15.01 \pm 0.27^{\mathrm{a}}$ \\
\hline $\begin{array}{c}\text { Penicillium } \\
\text { chrysogenum }\end{array}$ & $17.47 \pm 0.28^{\mathrm{b}}$ & $25.10 \pm 0.32^{\mathrm{b}}$ & $29.06 \pm 0.25^{\mathrm{b}}$ & $2.17 \pm 0.47^{\mathrm{b}}$ & $6.33 \pm 0.31^{\mathrm{b}}$ & $13.95 \pm 0.27^{\mathrm{a}}$ \\
\hline
\end{tabular}

Values are means \pm standard deviation of three replicates. Values in the same column with different superscript are significantly different at $P<0.05$.

Table 5. Antibacterial activity of leaves extracts of Moringa oleifera nanoparticles against selected bacteria

\begin{tabular}{|c|c|c|c|c|c|c|}
\hline \multirow{2}{*}{$\begin{array}{c}\text { Bacterial } \\
\text { Isolates }\end{array}$} & \multicolumn{2}{|c|}{$\begin{array}{c}\text { Extracts/Zones of Inhibition }(\mathrm{mm}) \\
\text { Ethanolic extract }(\mathrm{mg} / \mathrm{mL})\end{array}$} & \multicolumn{3}{c|}{$\begin{array}{c}\text { Aqueous extract } \\
(\mathrm{mg} / \mathrm{mL})\end{array}$} \\
\cline { 2 - 7 } & 10 & 20 & 30 & 10 & 20 & 30 \\
\hline $\begin{array}{c}\text { Escherichia } \\
\text { coli }\end{array}$ & $34.18 \pm 0.25^{\mathrm{a}}$ & $37.11 \pm 0.36^{\mathrm{a}}$ & $42.07 \pm 0.30^{\mathrm{a}}$ & $7.61 \pm 0.45^{\mathrm{b}}$ & $11.19 \pm 0.21^{\mathrm{a}}$ & $22.21 \pm 0.17^{\mathrm{a}}$ \\
\hline $\begin{array}{c}\text { Bacillus } \\
\text { megaterium }\end{array}$ & $35.74 \pm 0.37^{\mathrm{a}}$ & $43.28 \pm 0.26^{\mathrm{b}}$ & $49.21 \pm 0.32^{\mathrm{a}}$ & $12.18 \pm 0.48^{\mathrm{b}}$ & $15.73 \pm 0.36^{\mathrm{a}}$ & $20.15 \pm 025^{\mathrm{b}}$ \\
\hline $\begin{array}{c}\text { Staphylococcus } \\
\text { aureus }\end{array}$ & $30.26 \pm 0.26^{\mathrm{b}}$ & $33.52 \pm 0.41^{\mathrm{a}}$ & $45.35 \pm 0.40^{\mathrm{b}}$ & $14.35 \pm 0.53^{\mathrm{a}}$ & $17.95 \pm 0.29^{\mathrm{b}}$ & $26.71 \pm 0.38^{\mathrm{a}}$ \\
\hline $\begin{array}{c}\text { Pseudomonas } \\
\text { aeruginosa }\end{array}$ & $28.70 \pm 0.45^{\mathrm{a}}$ & $37.14 \pm 0.21^{\mathrm{a}}$ & $39.02 \pm 0.47^{\mathrm{a}}$ & $9.28 \pm 0.41^{\mathrm{b}}$ & $18.32 \pm 0.38^{\mathrm{a}}$ & $22.05 \pm 0.33^{\mathrm{b}}$ \\
\hline Bacillus subtilis & $22.35 \pm 0.38^{\mathrm{b}}$ & $26.34 \pm 0.39^{\mathrm{b}}$ & $38.41 \pm 0.22^{\mathrm{b}}$ & $10.16 \pm 0.35^{\mathrm{a}}$ & $14.08 \pm 0.16^{\mathrm{b}}$ & $17.37 \pm 0.24^{\mathrm{b}}$ \\
\hline
\end{tabular}

Values are means \pm standard deviation of three replicates. Values in the same column with different superscript are significantly different at $P<0.05$. 
Table 6. Antifungal activity of leaves extracts of Moringa oleifera nanoparticle

\begin{tabular}{|c|c|c|c|c|c|c|}
\hline \multirow{2}{*}{ Fungal Isolates } & \multicolumn{2}{|c|}{$\begin{array}{c}\text { Extracts/Zones of Inhibition }(\mathrm{mm}) \\
\text { Ethanolic extract }(\mathrm{mg} / \mathrm{mL})\end{array}$} & \multicolumn{3}{c|}{$\begin{array}{c}\text { Aqueous extract } \\
(\mathrm{mg} / \mathrm{mL})\end{array}$} \\
\cline { 2 - 7 } & 10 & 20 & 30 & 10 & 20 & 30 \\
\hline $\begin{array}{c}\text { Candida } \\
\text { albicans }\end{array}$ & $28.52 \pm 0.41^{\mathrm{a}}$ & $36.53 \pm 0.34^{\mathrm{b}}$ & $41.81 \pm 0.40^{\mathrm{a}}$ & $11.61 \pm 0.25^{\mathrm{b}}$ & $16.48 \pm 0.20^{\mathrm{a}}$ & $25.34 \pm 0.27^{\mathrm{b}}$ \\
\hline $\begin{array}{c}\text { Aspergillus } \\
\text { niger }\end{array}$ & $42.33 \pm 0.35^{\mathrm{b}}$ & $45.27 \pm 0.22^{\mathrm{a}}$ & $50.33 \pm 0.29^{\mathrm{b}}$ & $10.35 \pm 0.39^{\mathrm{b}}$ & $18.61 \pm 0.50^{\mathrm{a}}$ & $22.18 \pm 0.31^{\mathrm{a}}$ \\
\hline $\begin{array}{c}\text { Penicillium } \\
\text { chrysogenum }\end{array}$ & $29.06 \pm 0.17^{\mathrm{a}}$ & $33.15 \pm 0.27^{\mathrm{a}}$ & $41.01 \pm 0.31^{\mathrm{a}}$ & $17.43 \pm 0.26^{\mathrm{a}}$ & $25.25 \pm 0.33^{\mathrm{a}}$ & $29.35 \pm 0.39^{\mathrm{b}}$ \\
\hline
\end{tabular}

Values are means \pm standard deviation of three replicates. Values in the same column with different superscript are significantly different at $P<0.05$.

\section{Discussion}

The physicochemical properties of the leaves extract and its nanoparticles are presented in Table 1 . According to the data, it was observed that the nanoparticles possessed low $\mathrm{pH}$ of 3.46 and 3.05 in aqueous and ethanolic extract respectively which is synthesized in slightly acidic medium. The optimum $\mathrm{pH}$ for the synthesis of nanoparticles is 6 which is strongly dependent on the feature of the central metal ion. It was also observed that the $\mathrm{pH}$ formation of nanoparticles is less than 3 due to the presence of flavonoid in an undissociated form according to Maitera et al. (2018). The nanoparticle is non-electrolytic in nature which revealed conductivity at 10.18 due to its large surface area. The melting point of the nanoparticle is very low due to the environmental condition Mabhiza et al. (2016).

The phytochemical screening of the ethanolic leaves extract of Moringa oleifera showed the presence of alkaloids, saponins, steroids and tannins. The presence of the phytochemicals in the ethanolic extract is majorly responsible for its antimicrobial activity which might be due to the chemical constituents (secondary metabolites) that is being produced during the process of normal plants metabolism according to Oda et al. (2000). Based on previous work, it has been observed that ethanol can be used for extraction in most herbal medicinal plants in order to yield a pure and active compound Pal et al. (2007). It has been documented that $80 \%$ of leaf extracts are used for treatment by fighting against diseases worldwide Blanco et al. (2001). According to Mabhiza et al. (2016) antibacterial studies of alkaloid extracts from Callistemon citrinus and Vernonia adoensis against $S$. aureus and $P$. aeruginosa possessed the antibacterial activity as well as the inhibition of ATP-dependent transports of compounds through the microbial cell membranes. According to Ahmed et al. (2009), it has been observed that alcohol can be used for extraction in some medicinal plant in order to yield a good pure and active compound. Ethanol acts as the control which enhance the activities of the extracts. Based on the result obtained, it was observed that ethanolic extract was found to be more potent than the aqueous extract against the selected tested organisms. This might be as a result of a good solubility of the active composition of the leaves in ethanol than that of water Ezeifeka et al. (2004). This is in good agreement with the findings of Airaodion et al. (2019) who discussed the antibacterial activity of ethanolic extract and aqueous extracts of medicinal plant of Vernonia amygdalina leaves against some selected Gram $(+)$ and Gram (-) bacteria. Based on the data obtained, the zone of inhibition of the bacterial growth in ethanolic extract exhibited highest antibacterial activity. This is also in good agreement with the previous studies Aruljothi et al. (2014). From previous research, ethanol has been observed to be more useful in the extraction of leaves which is a good solvent for extraction and not toxic for human consumption Banskota et al. (2001). Ethanol is known to have higher polarity and has the ability to dissolve different types of compounds from plant materials inserted in them. Karaman et al. (2003) and Wei et al. (2008) also reported that ethanol and methanol are the most useful solvents for extraction of antibacterial compounds. According to Jayaraman et al. (2008) solvents such as ethanol and methanol can be used for extraction of antibacterial and antifungal 
compounds from M. citrifolia. There is proof from previous work that ethanol is more suitable than other solvents most especially water in the process of extracting the constituents of medicinal plants Ahmed et al. (2009) Cowan (1999) and Emad et al. (2009). According to the result obtained, antibacterial and antifungal activities indicated that the ethanolic (extracts) nanoparticle are more active than aqueous extract against the microorganisms. Based on the data obtained in the antifungal activity of the leaves extract nanoparticles, there was remarkable activity against the organisms which might be as a result of the coordination of the manganese oxides in the compound. The activity of plant nanoparticles is as a result of their high surface-to-volume ratio which allows them to be more active according to Prabhu and Poulose (2012). The compounds have the ability to cross the membranes of microbial cells by gaining access to target cells. The increase in antimicrobial studies might be as a result of the presence of phytochemicals in the leaves and their tendency to penetrate through the cell wall and cytoplasmic membranes of the organisms, thereby allowing the growth of inhibition zone in the organisms which agrees with Barnabas and Nagarajan (1988).

\section{Conclusions}

M. oleifera leaves extract has been synthesized with Manganese oxide nanoparticle possessing antibacterial and antifungal activities. It has been observed that the ethanolic extracts for both the leaves and its nanoparticle were found to exhibit higher activities than the aqueous extracts.

\section{Authors' Contributions}

Both authors read and approved the final manuscript.

\section{Acknowledgements}

This research received no specific grant from any funding agency in the public, commercial, or not-forprofit sectors.

\section{Conflict of Interests}

The authors declare that there are no conflicts of interest related to this article.

\section{References}

Abdallah EM, Khalid AS, Ibrahim N (2009). Antibacterial activity of oleo-gum resins of Commiphora molmol and Boswellia papyrifera against methicillin resistant Staphylococuss aureus (MRSA). Scientific Research and Essays $4(4): 351-356$.

Ahmed RN, Sani A, Ajiboye AE, Gambari-Ambali RO, Ezekiel K (2013). Sensitivity of three gastro-intestinal organisms to aqueous extract of leaf of Ocimum gratissimum. Nigeria Journal of Pure and Applied Sciences 26:2460-2469.

Ahmed RN, Sani A, Igunnugbemi OO (2009). Antifungal profiles of extracts of Vitellaria paradoxa (Shea-Butter) bark. Ethnobotanical Leaflets 6:2.

Airaodion AI, Ngwogu KO, Ngwogu AC, Ekenjoku JA (2019). Investigation of antibacterial activity of Vernonia amygdalina leaf extracts against gram-positive and gram-negative bacteria. International Journal of Bio-Science and Bio-Technology 11(11):87-93. 
Alzoreky NS, Nakahara K (2003). Antibacterial activity of extracts from some edible plants commonly consumed in Asia. International Journal of Food Microbiology 80:223-230. https://doi.org/10.1016/S0168-1605(02)00169-1

Aruljothi S, Uma C, Sivagurunathan P, Bhuvaneswari M (2014). Investigation on antibacterial activity of Carica papaya leaf extracts against wound infection-causing bacteria. International Journal of Research Studies in Biosciences $2(11): 8-12$.

Azwanida NN (2015). A review on the extraction methods use in medicinal plants, principle, strength and limitation. Medicinal and Aromatic Plants 4(196):2167-0412. https://doi.org/10.4172/2167-0412.1000196

Bamigboye MO, Ahmed RN (2019). Comparative antimicrobial activities of a consortium of Vernonia amygdalina and Amaranthus hybridus extracts with their $\mathrm{CuO}$ nanoparticle complexes. International Journal of Medical Review 6(1):31-34. https://doi.org/10.29252/IJMR-060107

Banskota AH, Tezuka Y, Kadota S (2001). Recent progress in pharmacological research of propolis. Phytotherapy Research 15(7):561-571. https://doi.org/10.1002/ptr.1029

Barnabas CG, Nagarajan S (1988). Antimicrobial activity of flavonoids of some medicinal plants. Fitoterapia 3:508-510.

Blanco JG, Gil RR, Bocco JL, Meragelman TL, Genti-Raimondi S, Flury A (2001). Aromatase inhibition by an 11,13dihydroderivative of a sesquiterpene lactone. Journal of Pharmacology and Experimental Therapeutics 297(3):1099-1105.

Cagin T, Che J, Qi Y, Zhou Y, Demiralp E, Gao G, Goddard WA (1999). Computational materials chemistry at the nanoscale. Journal of Nanoparticle Research 1:51-69. https://doi.org/10.1023/A:1010009630519

Castro SBR, Leal CA, Freire FR, Carvalho DA, Oliveira DF, Figueiredo HCP (2008). Antibacterial activity of plant extracts from Brazil against fish pathogenic bacteria. Brazilian Journal of Microbiology 39:756-760. https://doi.org/10.1590/S1517-838220080004000030

Cowan MM (1999). Plant products as antimicrobial agents. Clinical Microbiology Review 12:564-582. https://doi.org/10.1128/CMR.12.4.564

Daoud A, Malika D, Bakari S, Hfaiedh N, Mnafgui K, Kadri A (2019). Assessment of polyphenol composition, antioxidant and antimicrobial properties of various extracts of date palm pollen (DPP) from two Tunisian cultivar. Arabian Journal of Chemistry12(8):3075-3086. https://doi.org/10.1016/j.arabjc.2015.07.014 30753086

Doddanna SJ, Patel S, Sundarrao MA, Veerabhadrappa RS (2013). Antimicrobial activity of plant extracts on Candida albicans: an in vitro study. Indian Journal of Dental Research 24:401-405. https://doi.org/10.4103/09709290.118358

Enemose EA, Akporhonor EE, Kpomah B (2018). Preparation and evaluation of mixed-ligand complexes of Cu (II) and Co (II) with amodiaquine hydrochloride and sulphamethazine. Journal of Applied Sciences and Environmental Management 22(6):933-936. https://doi.org/10.4314/jasem.v22i6.16

Ezeifeka GO, Orji MU, Mbata TI, Patrick AO (2004). Antimicrobial activities of Cajanus cajan, Garcinia kola and Xylopia athiopica on pathogenic microorganisms. Biotechnology 3(1):41-43. https://doi.org/10.3923/biotech.2004.41.43

Jana NR, Gearheart L, Murphy CJ (2001). Wet chemical synthesis of silver nanorods and nanowires of controllable aspect ratioElectronic supplementary information (ESI) available: UV-VIS spectra of silver nanorods. Chemical Communications 7:617-618.

Jayaraman SK, Manoharan MS, Illanchezian S (2008). Antibacterial, antifungal and tumor cell suppression potential of Morinda citrifolia fruit extracts. International Journal of Integrative Biology 3:44-49.

Karaman I, Sahin F, Gulluce M, Ogutcu H, Sengul M, Adiguzel A (2003). Antimicrobial activity of aqueous and methanol extracts of Juniperus oxycedrus L. Journal of Ethnopharmacology 85(2-3):231- 235. https://doi.org/10.1016/s0378-8741(03)00006-0

Kensa VM, Neelamegam R (2014). Evaluation of haematological properties of normal Albino rats exposed to ethanolic extract of Hydrilla verticillata (L.F.) collected from unpolluted and polluted water sources. International Journal of Current Microbiology and Applied Sciences 3(12):409-416.

Mabhiza D, Chitemerere T, Mukanganyama S (2016). Antibacterial properties of alkaloid extracts from Callistemon citrinus and Vernonia adoensis against Staphylococcus aureus and Pseudomonas aeruginosa. International Journal of Medicinal Chemistry. https://doi.org/10.1155/2016/6304163

Maitera ON, Louis H, Barminas JT, Akakuru OU, Boro G (2018). Synthesis and characterization of some metal complexes using herbal flavonoids. National Products Chemistry and Research 6:314. https://doi.org/10.4172/2329-6836.1000314 
Mau JL, Chen CP, Hsieh PC (2001). Antimicrobial effect of extracts from Chinese chive, cinnamon, and corni fructus. Journal of Agricultural and Food Chemistry 49:183-188. https://doi.org/10.1021/jf000263c

Oda K, Matsuda H, Murakami T, Katayama S, Ohgitani T, Yoshikawa M (2000). Adjuvant and haemolytic activities of 47 saponins derived from medicinal and food plants. Biological Chemistry 381(1):67-74. https://doi.org/10.1515/BC.2000.009

Pal S, Tak YK, Song JM (2007). Does the antibacterial activity of silver nanoparticles depend on the shape of the nanoparticle? A study of the Gram-negative bacterium, Escherichia coli. Applied Environmental Microbiology 73(6):1712-1720. https://doi.org/10.1128/aem.02218-06

Pirtarighat S, Ghannadnia M, Baghshahi S (2019). Green synthesis of silver nanoparticles using the plant extract of Salvia spinosagrown in vitro and their antibacterial activity assessment. Journal of Nanostructure in Chemistry 9(1):19. https://doi.org/10.1007/s40097-018-0291-4

Prabhu S, Poulose EK (2012). Silver nanoparticles: mechanism of antimicrobial action, synthesis, medical applications, and toxicity effects. International Nano Letters 2(1):32. https://doi.org/10.1186/2228-5326-2-32

Ramakrishna D, Pragna R (2011). Nanoparticles: is toxicity a concern? The Journal of the International Federation of Clinical Chemistry and Laboratory Medicine 22(4):92-101.

Sharma AK, Gangwar M, Tilak R, Nath G, Sinha ASK, Tripathi YB, Kumar DC (2012). Comparative in vitro antimalarial and phyto-chemical evaluation of methanolic extract of root, stem and leaf of Jatropha curcas Linn. Pharmacognosy Journal 4(30):34-40. https://doi.org/10.5530/pj.2012.30.7

Wei LS, Musa N, Sengm CT, Wee W, Shazili NAM (2008). Antimicrobial properties of tropical plants against 12 pathogenic bacteria isolated from aquatic organisms. African Journal of Biotechnology 7(13):2275-2278. https://doi.org/10.5897/AJB08.915

Wong ST, Lee JF, Chen JM, Mou CY (2001). Preparation and characterization of MCM-41 and silica supported nickel boride catalysts. Journal of Molecular Catalysis A: Chemical 165(1-2):159-167. https://doi.org/10.1016/s1381-1169(00)00409-X

Yakubu MT, Adesokan AA, Akanji MA (2006). Biochemical changes in the liver, kidney and serum of rat following chronic administration of cimetidine. African Journal of Biomedical Research 9(3):213-218. https://doi.org/10.4314/ajbr.v9i3.48908

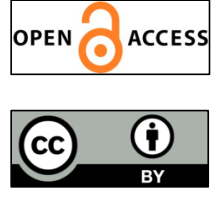

The journal offers free, immediate, and unrestricted access to peer-reviewed research and scholarly work. Users are allowed to read, download, copy, distribute, print, search, or link to the full texts of the articles, or use them for any other lawful purpose, without asking prior permission from the publisher or the author.

License - Articles published in Notulae Scientia Biologicae are Open-Access, distributed under the terms and conditions of the Creative Commons Attribution (CC BY 4.0) License.

(c) Articles by the authors; SHST, Cluj-Napoca, Romania. The journal allows the author(s) to hold the copyright/to retain publishing rights without restriction. 